\title{
Incorporation of Onium System with Cloud Point Extraction and Determination of Iron(III) and Mercury(II) in Different Samples
}

\author{
SHAWKET KADHIM JAWAD ${ }^{1 *}$, MOSA OMRAN KADHIM ${ }^{1}$ and EBAA ADNAN AZOOZ ${ }^{2}$
}

\author{
${ }^{1}$ Chemistry Department, Education Faculty for Women, Kufa University, Al-Najaf-31001, Iraq. \\ ${ }^{2}$ The general directorate of education Al-Najaf Al- Ashraf, Al-Thakawat School. \\ *Corresponding author E-mail: Shawkat.alshakarchi@uokufa.edu.iq, musaaldagher@uokufa.edu.iq, \\ 2ebaaadnan665@gmail.com.
}

http://dx.doi.org/10.13005/ojc/330433

(Received: May 28, 2017; Accepted: June 28, 2017)

\begin{abstract}
By joined two sensitive methods which in onium method and Cloud point extraction method CPE for separation preconcentration and extraction $\mathrm{Fe}^{3+}$ and $\mathrm{Hg}^{2+}$ by using (BAEE) from acidic hydrochloric aqueous solution in the presence TritonX-100. Spectrophotometric studies shows wave length for maximum absorbance to onium species of $\mathrm{Fe}(\mathrm{III})$ was $\lambda_{\max }=362 \mathrm{~nm}$ and for $\mathrm{Hg}$ (II) $\lambda_{\max }=293 \mathrm{~nm}$. Optimum condition studies was $1 \mathrm{M} \mathrm{HCl}$ for both ions, $100 \mu \mathrm{g}$ of each metal ions , using $1 \times 10^{-4} \mathrm{M}$ of (BAEE), as well as the method need heating for $85^{\circ} \mathrm{C}$ to $\mathrm{Fe}^{3+}$ and $95^{\circ} \mathrm{C}$ for $\mathrm{Hg}^{2+}$ ion and heating time $15 \mathrm{~min}$. for $\mathrm{Fe}^{3+}$ and $20 \mathrm{~min}$. for $\mathrm{Hg}^{2+}$ ion. so that need existance $0.5 \mathrm{~mL}$ of TritonX-100 for both metal ion, the research involved many other studies. Thermodynamic data of $\mathrm{Fe}^{3+} \mathrm{and} \mathrm{Hg}^{2+}$ was $\Delta \mathrm{H}_{\mathrm{ex}}=0.195,0.0592 \mathrm{~kJ} \mathrm{~mol}^{-1}, \Delta \mathrm{G}_{\mathrm{ex}}=-66.480,-77.981 \mathrm{kJmol}^{-1}, \Delta \mathrm{S}_{\mathrm{ex}}=186.245,212.065 \mathrm{Jmol}^{-1} \mathrm{~K}^{-1}$, respectively, application and spectrophotometric determination of $\mathrm{Fe}^{3+}$ ion and $\mathrm{Hg}^{2+}$ ion in different samples.
\end{abstract}

Keyword: Cloud point extraction, onium system, N $\alpha$-Benzoyl-L-arginine ethyl ester hydrochloride (BAEE), mercury, iron.

\section{INTRODUCTION}

Iron is known as one of the essential nutritional elements for many living organisms due to its role in most of metabolic processes, including oxygen and electron transport, and DNA synthesis. exposure to excess iron can cause several diseases or disorders such as endocrine problems, arthritis, diabetes and liver disease $e^{1,2}$. Mercury is a toxic element found throughout the environment. Its mobile nature allows it to diffuse through the air, soils and ultimately into water systems ${ }^{3}$ Trace determination of heavy metals is one of the most important issues of chemical analysis ${ }^{4}$ In 1978, Watanab introduced cloud point extraction (CPE) as a new extraction method for determination of Zn with I-(2-Pyridylazo)2-Naphthol ligand 5 . Since then CPE was applied widely for determination of various analytes ${ }^{6,7}$, mainly for the extraction of metal ions ${ }^{8,11}$. The most important feature of CPE is application of a surfactant, mostly 
non-ionic as the extractant phase ${ }^{12}$ which means that CPE avoids the consumption of large amounts of expensive, toxic and flammable organic solvents ${ }^{13}$. Use crown ether DB18C6 and from acidic $\mathrm{HCl}$ media extracted $\mathrm{Fe}^{3+}$ ion by application $\mathrm{CPL}$ after change $\mathrm{Fe}^{3+}$ into $\mathrm{FeCl}_{4}^{-}$TritonX-100 was necessary to obtained higher extraction efficiency Thermodynamic data was $\Delta \mathrm{H}_{\mathrm{ex}}=0.159 \mathrm{~kJ} \mathrm{~mol}^{-1}, \Delta \mathrm{G}_{\mathrm{ex}}=-62.43 \mathrm{~kJ}$ $\mathrm{mol}^{-1}, \Delta \mathrm{S}_{\mathrm{ex}}=174.83 \mathrm{~J} \mathrm{~mol}^{-1} \mathrm{~K}^{-1}$, there are another empirical application for this study in real samples ${ }^{14}$. Used CPE methodology for determination $\mathrm{Hg}^{2+}$ in different tissues of grilled chickens with application clod vapors atomic absorption and organic agent (DDTP) so Triton $\mathrm{X}-114^{15}$. By application of CPE method coupled with spectrophotometric technique for extraction and determination of $\mathrm{Hg}^{2+}$ in different samples of fish, new thiazolylazo reagent was synthesized 7-(6-Bromo2-benzothiazolylazo)8-Hydroxyquinoline and Triton X-114 at specific $\mathrm{pH}=5, \mathrm{DOL}=7.4 \mathrm{ng} \mathrm{mL}^{-1} 16$.Sensitive application method of solvent extraction used onium system for extraction $\mathrm{Zn}^{2+}$ from acidic aqueous solution of $\mathrm{HCl}$ as oxonium species by using methyl stearate Stearate as sensitive extract ant dissolved in chloroform the study show extracted species giving maximum absorbance at wave length $\lambda_{\max }=275 \mathrm{~nm}$, Sandell's sensitivity $=0.00832 \mu \mathrm{g} . \mathrm{cm}^{-2}{ }^{18}$.

\section{EXPERIMENTAL}

\section{Materials and solutions}

For spectroscopic studies and absorbance measurements used double beam spectrophotometer (Biochrom Libra 560) (UK)so that used Electrostatic water bath (WNB7-45) (England) for heating to CPT, as well as all experiments needed balance (A \& D company, Limited, Dool, CE, HR 200, Japan) $( \pm 0.0001 \mathrm{~g})$.

For preparing all the solutions needing in experiment used high purity materials received from commercial sources without further purification and used Doubly distilled water with set of suitable glassware, stock solution $1 \mathrm{mg} / \mathrm{mL}$ of $\mathrm{Fe}^{3+}$ ion

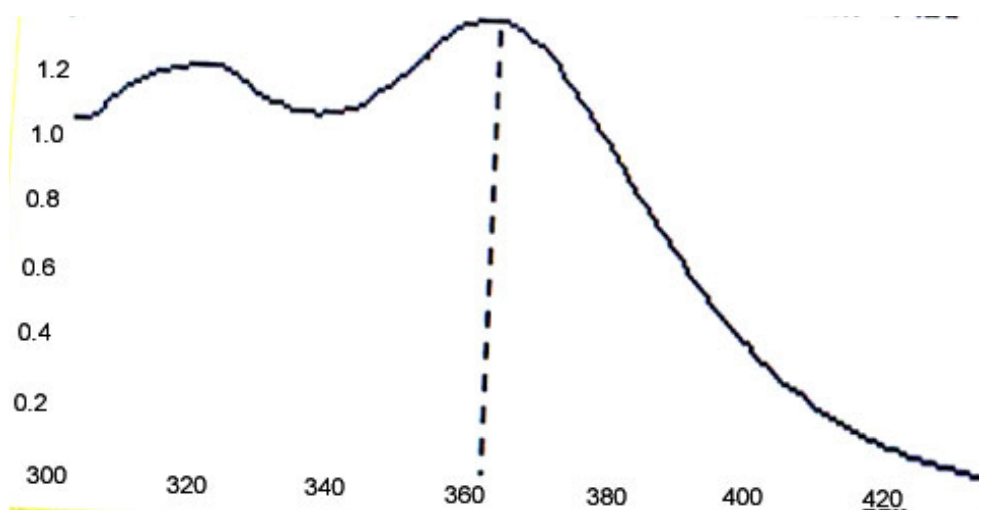

Fig. 1: UV-VIS. absorption spectrum for onium species of $\mathrm{Fe}^{3+}$.

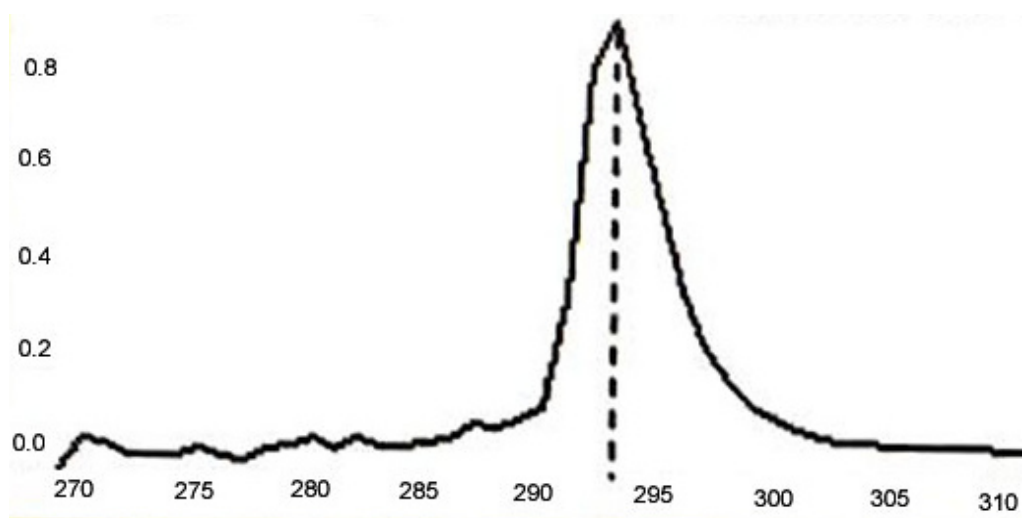

Fig. 2: UV-VIS. absorption spectrum for onium species of $\mathrm{Hg}^{2+}$. 
prepared by dissolving $0.2880 \mathrm{gm}$ in of $\mathrm{FeCl}_{3}$ in $100 \mathrm{~mL}$ and for $\mathrm{Hg}^{2+}$ ion dissolved $0.1353 \mathrm{gm}$ of $\mathrm{HgCl}_{2}$ in $100 \mathrm{~mL}$ of distilled water other working solutions preparing by dilution method with distilled water in suitable volumetric flask, so $1 \times 10^{-2} \mathrm{M}$ of $\mathrm{N} \alpha$-Benzoyl-L-arginine ethyl ester hydrochloride (BAEE) was prepared by dissolving $(0.08571 \mathrm{gm})$ in $(25 \mathrm{~mL})$ distilled water. Other working solutions were prepared by dilution method with distilled water.

\section{Comprehensive method}

$10 \mathrm{~mL}$ aqueous solution contain $100 \mu \mathrm{g}$ of metal ion under study $\mathrm{Fe}^{3+}$ and $\mathrm{Hg}^{2+}$ with optimum concentration $\mathrm{HCl}$ and $1 \times 10^{-4} \mathrm{M}$ (BAEE), in the presence $0.5 \mathrm{~mL}$ of non-ionic surfactant Triton X-100. Heating the solution in electrostatic water bath for suitable temperature and time until formation cloud point layer then separated CPL from aqueous solution and dissolved CPL in $5 \mathrm{~mL}$ ethanol. The absorbance of alcoholic solution is measured at $\lambda_{\text {max }}=362 \mathrm{~nm}$ for $\mathrm{Fe}^{3+}$ and $\lambda_{\text {max }}=293 \mathrm{~nm}$ for $\mathrm{Hg}^{2+}$ ion against blank prepared in the same manner without metal ions. But aqueous solution for $\mathrm{Fe}^{3+}$ ion treated according to thiocyanate method but $\mathrm{Hg}^{2+}$ ion treated according to Dithiazone spectrophotometric method $^{18}$ to determine remainder quantity of metal ions in aqueous solution after extraction and subtraction this quantity from original quantity $100 \mu \mathrm{g}$ to determine the transferred quantity to CPL to formation onium species extracted then calculated distribution ratio (D).

$\boldsymbol{D}=\left[\mathrm{M}^{\mathrm{n}+}\right]_{\mathrm{CPL}} /\left[\mathrm{M}^{\mathrm{n}+}\right]_{\mathrm{aq}}$

Whereas $\mathrm{M}^{+n}=\mathrm{Fe}^{3+} \& \quad \mathrm{Hg}^{2+}$

\section{RESULTS AND DISCUSSION}

\section{Spectrophotometry}

$10 \mathrm{~mL}$ aqueous solution contain $100 \mu \mathrm{g}$ of $\mathrm{Fe}^{3+} \mathrm{Or} \mathrm{Hg}{ }^{2+}$ with $1 \mathrm{M} \mathrm{HCl}$ and $1 \times 10^{-4} \mathrm{M}$ (BAEE), $0.5 \mathrm{~mL} 1 \%$ Triton $X-100$. Heating the solution in electrostatic water bath for suitable temperature and time until formation cloud point layer CPL with

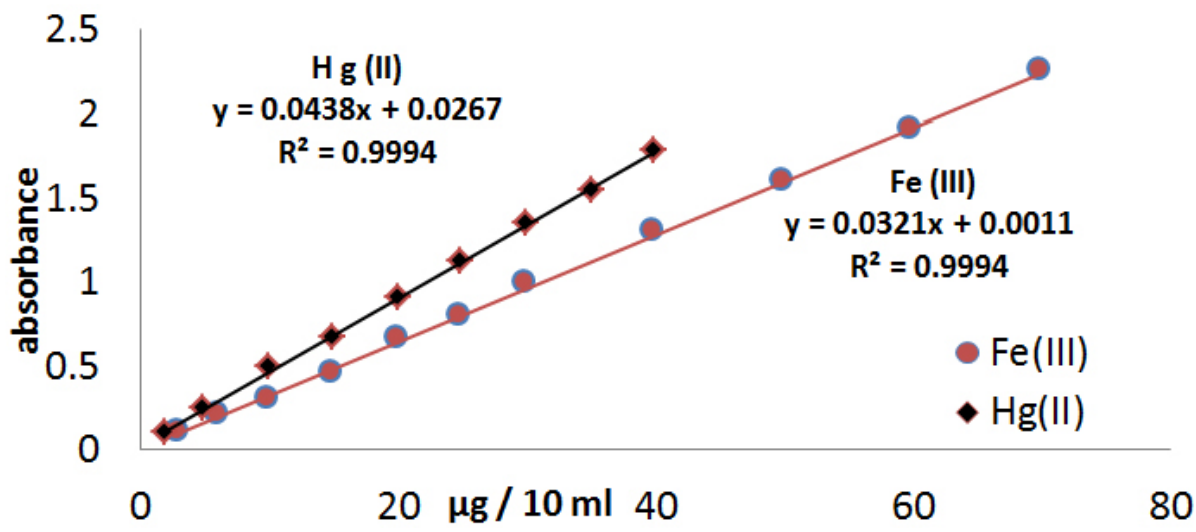

Fig. 3: calibration curve for determination metal ions in aqueous solutions.

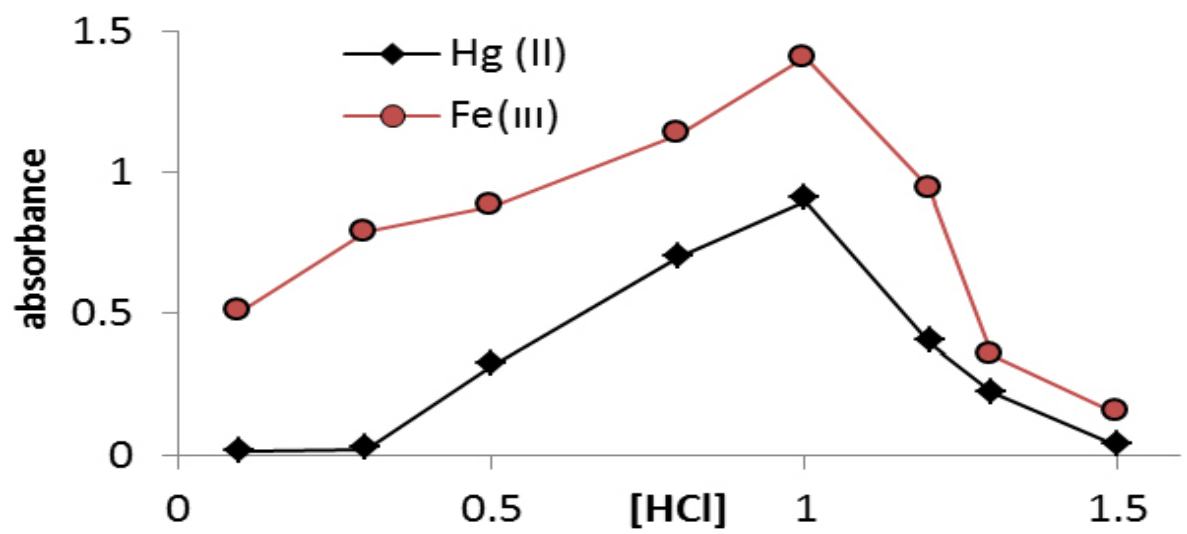

Fig. 4: effect of $\mathrm{HCl}$ concentration on formation and stability of onium species 
smaller volume then volume, then separated CPL from aqueous solution and dissolved $\mathrm{CPL}$ in $5 \mathrm{~mL}$ ethanol and talking absorption spectrum in (UV-Vis) region against blank prepared in the same manner without metal ions. The results were as in Figures 1 and 2.

The spectrum show wave length for the maximum the absorbance of onium species of $\mathrm{Fe}^{3+}$ ion was $\lambda_{\max }=362 \mathrm{~nm}$ but onium species of $\mathrm{Hg}^{2+}$ ion was $\lambda_{\max }=293 \mathrm{~nm}$.

Table 1: Thermodynamic data of extraction

\begin{tabular}{|c|c|c|c|}
\hline $\begin{array}{l}\text { Metal } \\
\text { ions }\end{array}$ & $\underset{\mathrm{kJ} \mathrm{mol}^{-1}}{\Delta \mathrm{H}_{\mathrm{ex}}}$ & $\underset{\mathbf{k J ~ m o l}^{-1}}{\Delta \mathbf{G}_{\mathrm{ex}}}$ & $\begin{array}{c}\Delta \mathbf{S}_{\mathrm{ex}} \\
\mathrm{J} \mathrm{mol}^{-1} \mathbf{K}^{-1}\end{array}$ \\
\hline $\mathrm{Fe}^{3+}$ & 0.195 & -66.48 & 186.254 \\
\hline $\mathrm{Hg}^{2+}$ & 0.0592 & -77.981 & 212.065 \\
\hline
\end{tabular}

Variation of hydrochloric acid concentration

Two set $10 \mathrm{~mL}$ aqueous solutions contain $100 \mu \mathrm{g}$ of $\mathrm{Fe}^{3+} \mathrm{Or} \mathrm{Hg}^{2+}$ with different concentration

Table 2: Effect of electrolyte on extraction efficiency of $\mathrm{Fe}^{3+}$ or $\mathrm{Hg}^{2+}$ ions.

\begin{tabular}{|c|c|c|c|c|}
\hline \multirow{2}{*}{$\begin{array}{l}\text { Electrolyte } \\
\text { salts }\end{array}$} & \multicolumn{2}{|l|}{$\mathrm{Fe}^{3+}$} & \multicolumn{2}{|l|}{$\mathrm{Hg}^{2+}$} \\
\hline & $\begin{array}{c}\text { Abs. } \\
362 \mathrm{~nm}\end{array}$ & D & $\begin{array}{c}\text { Abs. } \\
293 \mathrm{~nm}\end{array}$ & D \\
\hline $\mathrm{LiCl}$ & 1.832 & 114.45 & 1.725 & 218.5 \\
\hline $\mathrm{NaCl}$ & 1.716 & 106.31 & 1.631 & 183.3 \\
\hline $\mathrm{KCl}$ & 1.638 & 99 & 1.51 & 165.7 \\
\hline $\mathrm{NH}_{4} \mathrm{Cl}$ & 1.601 & 91.51 & 1.48 & 151.4 \\
\hline $\mathrm{MgCl}_{2}$ & 1.813 & 109.52 & 1.646 & 192.8 \\
\hline $\mathrm{CaCl}_{2}$ & 1.616 & 94.53 & 1.575 & 171.21 \\
\hline
\end{tabular}

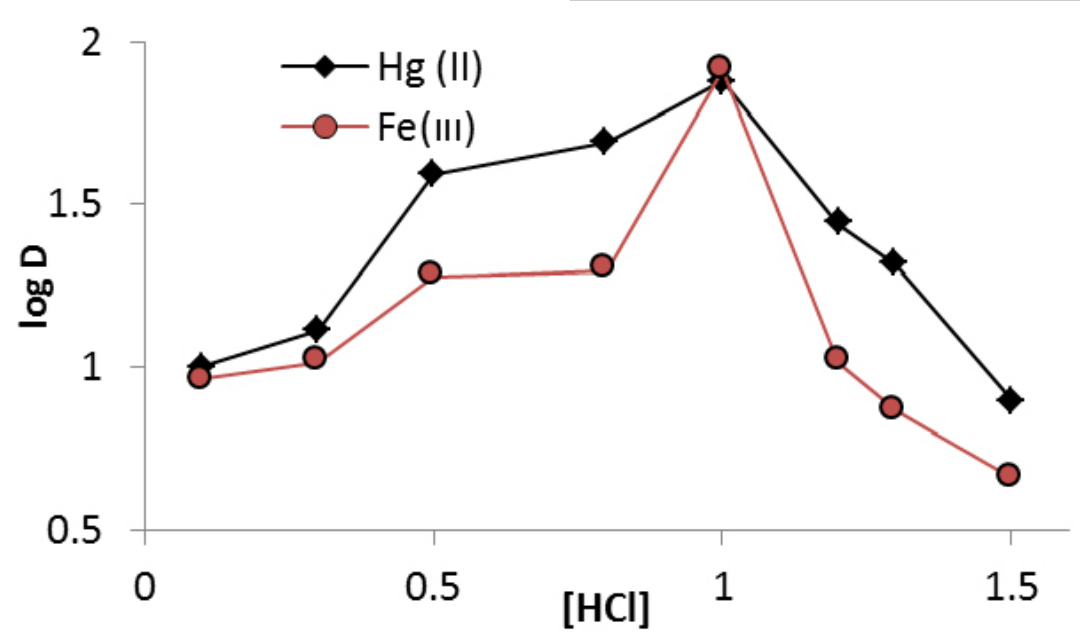

Fig. 5: effect of $\mathrm{HCl}$ concentration on extraction efficient and $\mathrm{D}$ value

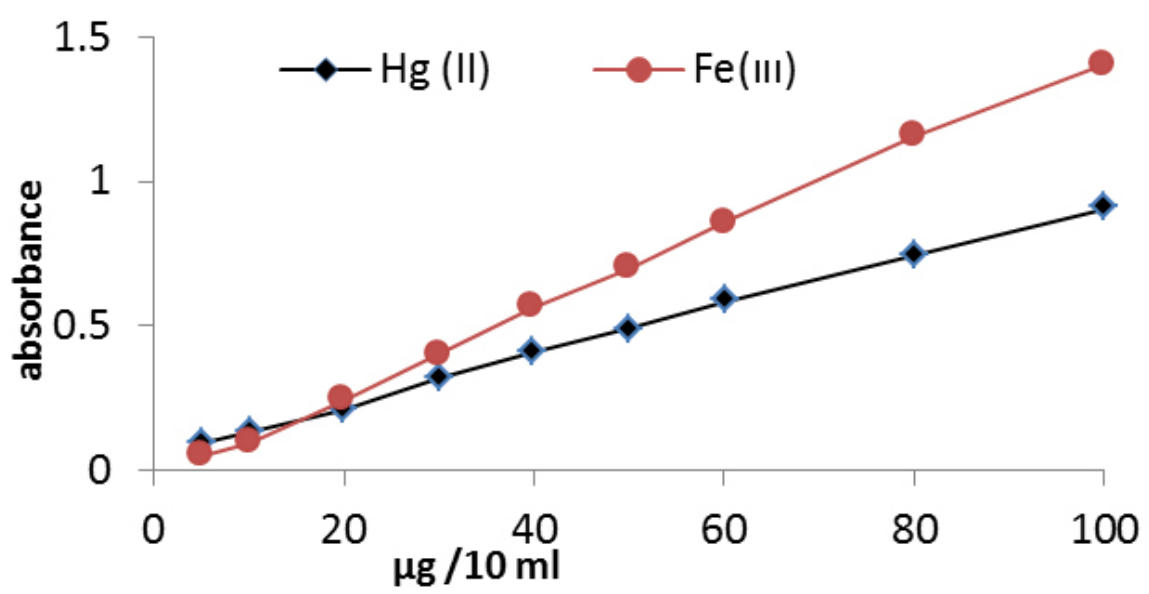

Fig. 6: effect of metal ions concentration on formation and stability of onium species extracted 
$\mathrm{HCl}$ and $1 \times 10^{-4} \mathrm{M}$ (BAEE), $0.5 \mathrm{~mL} 1 \%$ Triton X-100. Heating the solution to suitable temperature and time until formation CPL, then separated CPL from aqueous solution and complete the procedure according to comprehensive method. The results were as in Figures 4 and 5.

The results shows $1 \mathrm{M} \mathrm{HCl}$ was the optimum molar concentration of $\mathrm{HCl}$ in aqueous solution for extraction onium species of $\mathrm{Fe}^{3+}$ and $\mathrm{Hg}^{2+}$ ions at this molar concentration reached to higher extraction efficiency appear higher absorbance and $D$ values because at this molar concentration reached to favorable equilibrium of formation onium species so that partitioning into cloud point layer CPL

$4 \mathrm{HCl}+\mathrm{Fe}^{3+}+4 \mathrm{H}_{2} \mathrm{O} \leftrightarrow \mathrm{H}\left(\mathrm{H}_{2} \mathrm{O}\right)_{4}{ }^{+} ; \mathrm{FeCl}_{4}{ }^{-}+3 \mathrm{H}^{+}$

$\mathrm{H}\left(\mathrm{H}_{2} \mathrm{O}\right)_{4}^{+} ; \mathrm{FeCl}_{4}^{-}+3 \mathrm{BAEE} \leftrightarrow \mathrm{H}\left(\mathrm{H}_{2} \mathrm{O}\right)(\mathrm{BAEE})_{3}{ }^{+} ; \mathrm{FeCl}_{4}$ $+3 \mathrm{H}_{2} \mathrm{O}$

Table 3: Effect of interferences on extraction efficiencies

\begin{tabular}{lcccc}
\hline Interferences & $\mathbf{F e}^{3+}$ & \multicolumn{3}{c}{$\mathbf{H g}^{2+}$} \\
\hline & $\begin{array}{c}\text { Abs. } \\
\mathbf{3 6 2} \mathbf{~ n m}\end{array}$ & $\mathbf{D}$ & $\begin{array}{c}\text { Abs. } \\
\mathbf{2 9 3} \mathbf{~ n m}\end{array}$ & $\mathbf{D}$ \\
\cline { 2 - 5 } & 0.235 & 16.56 & 0.469 & 40.11 \\
$\mathrm{Ni}^{2+}$ & 0.328 & 22.12 & 0.321 & 28.65 \\
$\mathrm{Co}^{2+}$ & 0.807 & 57.44 & 0.646 & 60.34 \\
$\mathrm{Cd}^{2+}$ & 0.61 & 40.57 & 0.478 & 47.32 \\
$\mathrm{Cu}^{2+}$ & 0.689 & 43.83 & 0.701 & 80.51 \\
$\mathrm{Zn}^{2+}$ & 0.901 & 63.81 & 0.512 & 54.47 \\
$\mathrm{Mn}^{2+}$ & & & & \\
\hline
\end{tabular}

$\mathrm{H}\left(\mathrm{H}_{2} \mathrm{O}\right)(\mathrm{BAEE})_{3}{ }^{+} ; \mathrm{FeCl}_{4}{ }^{-}($Aqua $) \leftrightarrow \mathrm{H}\left(\mathrm{H}_{2} \mathrm{O}\right)(\mathrm{BAEE})_{3}{ }^{+}$ $; \mathrm{FeCl}_{4}-(\mathrm{CPL})$

Any concentration of $\mathrm{HCl}$ less than optimum value being not enough to reach favorable equilibria and giving decline in extraction efficiency so that any concentration of $\mathrm{HCl}$ in aqueous solution more than optimum value effect to decrease extraction efficiency because effect to increase the rate of backward direction of equilibrium.

\section{Effect of metal ions concentration}

Extracted $\mathrm{Fe}^{3+}$ or $\mathrm{Hg}^{2+}$ according to onium system as detailed in comprehensive method from $10 \mathrm{~mL}$ aqueous solutions contain rising quantity of metal ions with existence $1 \mathrm{M} \mathrm{HCl}$ The results were as in Figures 6 and 7.

The results appear linear relation between extraction efficiency and metal ion concentration in aqueous solution to optimum value of metal ion concentration equal to $100 \mu \mathrm{g}$ at constant of other constant conditions, that in mean increasing in onium species formation and partitioning to $\mathrm{CPL}$ with increasing metal ion concentration.

\section{Rising BAEE concentration effect}

Extracted $100 \mu \mathrm{g}$ of each metal ion under study in $10 \mathrm{~mL}$ aqueous solutions by rising concentration of BAEE at constant other condition according to comprehensive method, The results were as in Figures $(8,9)$ (8 and 9):

The results shows linear relation and reflect increasing in onium species concentration formation

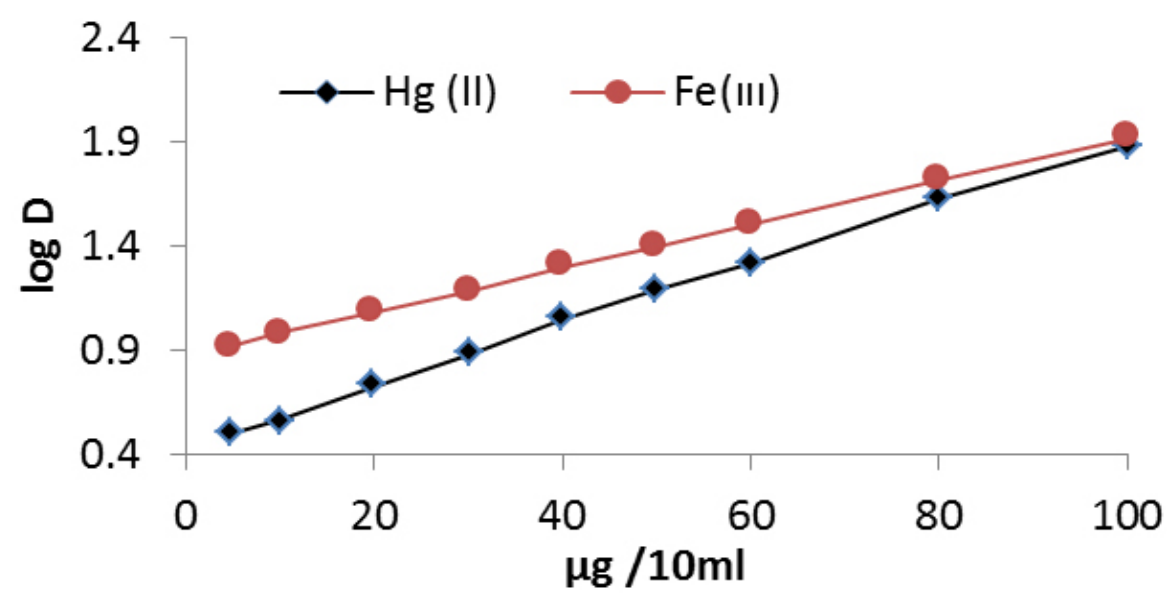

Fig. 7: $D=f[$ metal ions ] 
and stability with increasing concentration of BAEE, that is mean BAEE is un thermodynamic parameter which in it increasing concentration effect to increase that rate of forward direction of formation onium species with increasing concentration of onium species formed.

\section{Thermodynamic}

Effect of temperature on extraction efficiency of onium species by joining onium system and CPE methods involved extraction $100 \mu \mathrm{g}$ in 10 $\mathrm{mL}$ aqueous solutions of each ion in presence $1 \mathrm{M}$ $\mathrm{HCl}, 1 \times 10^{-4} \mathrm{M}$ (BAEE), $0.5 \mathrm{~mL} 1 \%$ Triton $\mathrm{X}-100$ at

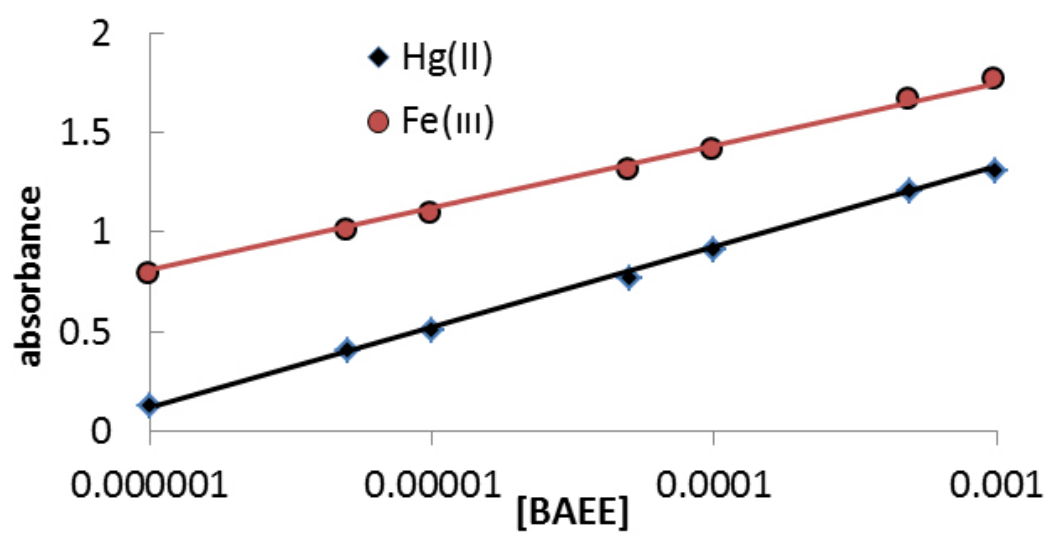

Fig. 8: Effect of BAEE concentration on formation and stability of onium species extracted.

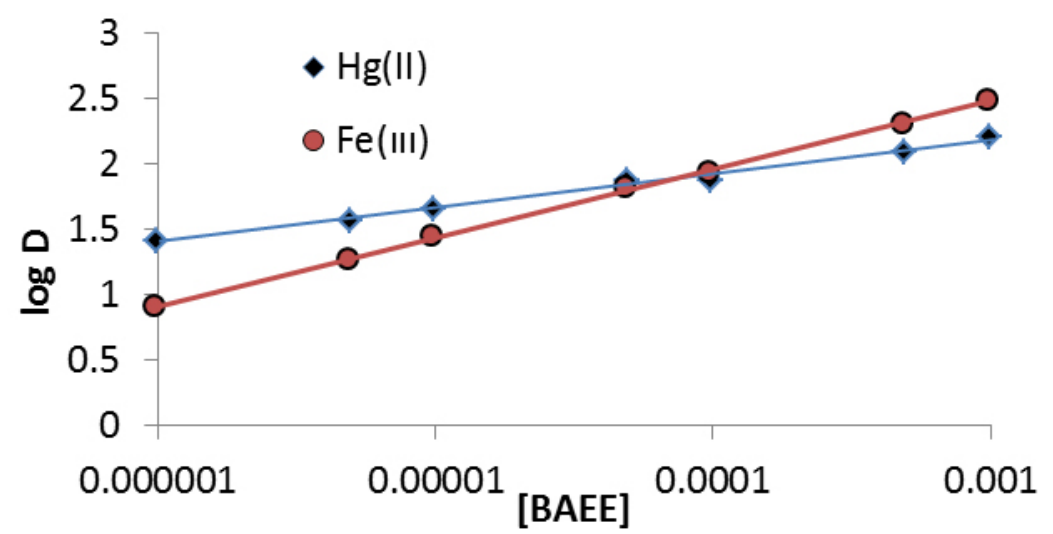

Fig. 9: Effect of BAEE concentration on extraction efficient and $D$ value

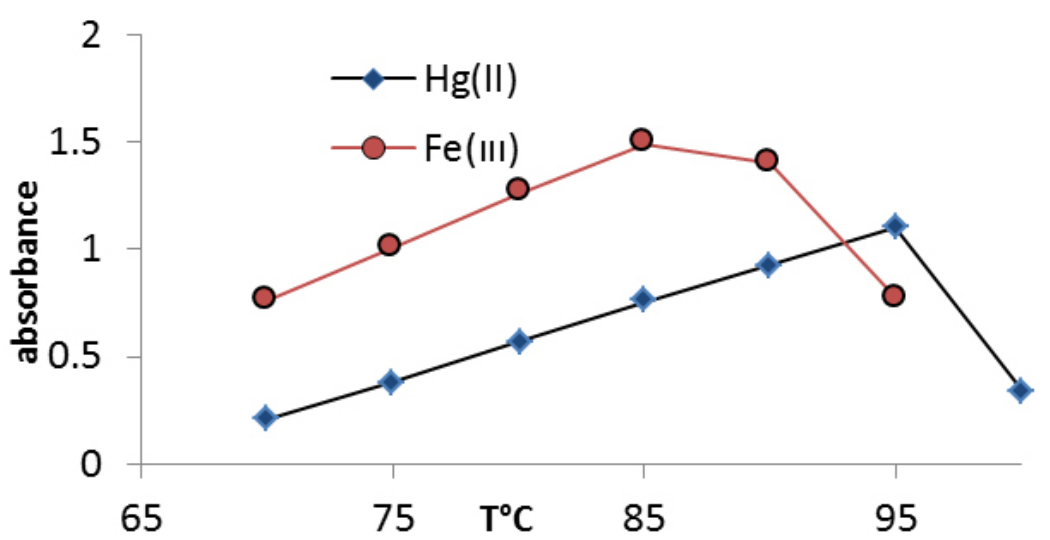

Fig. 10: effect temperature on formation CPL and extraction 
rising temperature with 15 minutes of heating at each temperature according to comprehensive method. The results were as in Figures 10 and 11.

The extraction method shows $85^{\circ} \mathrm{C}$ was optimum temperature for extraction $\mathrm{Fe}^{3+}$ ion but $95^{\circ} \mathrm{C}$ for extraction $\mathrm{Hg}^{2+}$ after calculated extraction constant $\mathrm{K}_{\mathrm{ex}}$ for each ion by following the relation (2).

$$
\boldsymbol{K}_{\text {ex }}=\frac{\boldsymbol{D}}{\left[\boldsymbol{M}^{\boldsymbol{n}+}\right][\mathrm{BAEE}]}
$$
Figure12.

Diagram log $\mathrm{K}_{\mathrm{ex}}$ against $1 / \mathrm{T} \mathrm{K}$ as in fig

From the slopes of straight lines in figure12 and relations (3-5) calculated thermodynamic data of extraction as in table(1).

slope $=-\Delta H_{e x} / 2.303 R$

$\Delta \mathrm{G}_{\mathrm{ex}}=-\mathrm{RT} \operatorname{Ln} \mathrm{K}_{\mathrm{ex}}$

$\Delta \mathrm{G}_{\mathrm{ex}}=\Delta \mathrm{H}_{\mathrm{ex}}-\mathrm{T} \Delta \mathrm{S}^{\mathrm{ex}}$

At the optimum temperature reaching the thermodynamic equilibrium to formation CPL with favorable distribution to CPL to giving best extraction efficiency.

\section{Effect of heating time.}

According to comprehensive method extracted $\mathrm{Fe}^{3+}$ and $\mathrm{Hg}^{2+}$ from $10 \mathrm{~mL}$ aqueous solutions involved $100 \mu \mathrm{g}$ of each metal ions and $1 \mathrm{M} \mathrm{HCl}, 1 \times 10^{-4} \mathrm{M}$ (BAEE), $0.5 \mathrm{~mL} 1 \%$ Triton $\mathrm{X}-100$. Heating at optimum temperature for rising time The
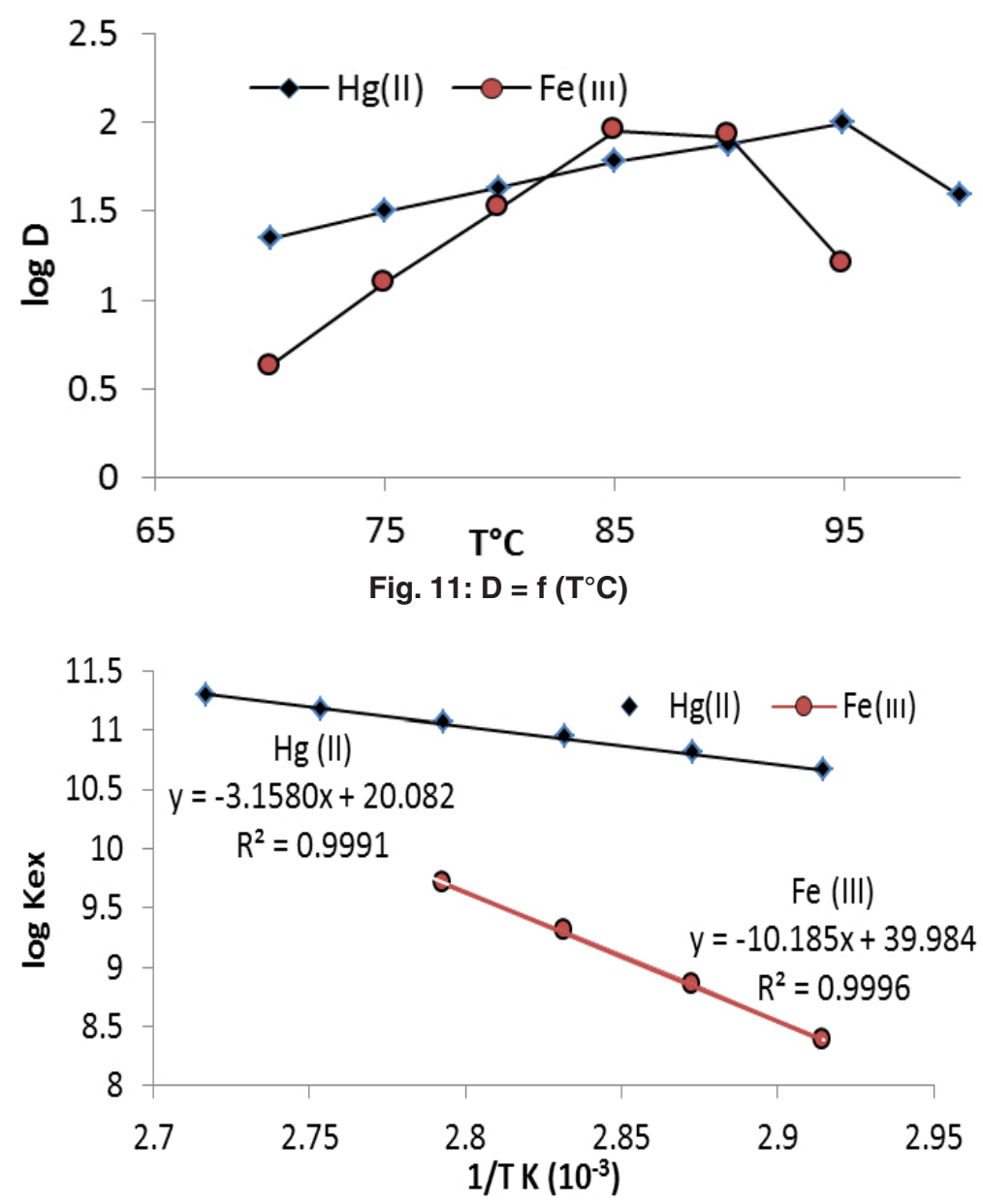

Fig. 12: effect of temperature on extraction constant. 
time. The results were as in fig Figures 13 and 14.

The results shows (15 $\mathrm{min})$ was the optimum heating time for extraction $\mathrm{Fe}^{3+}$ but for extraction $\mathrm{Hg}^{2+}$ ion needing (20 min) for heating.
Whereas the heating time represents kinetic side of extraction, at extraction at optimum value reach best equilibrium of CPL with higher density and small volume, as well as favorable dehydration at any heating time less than optimum not reached

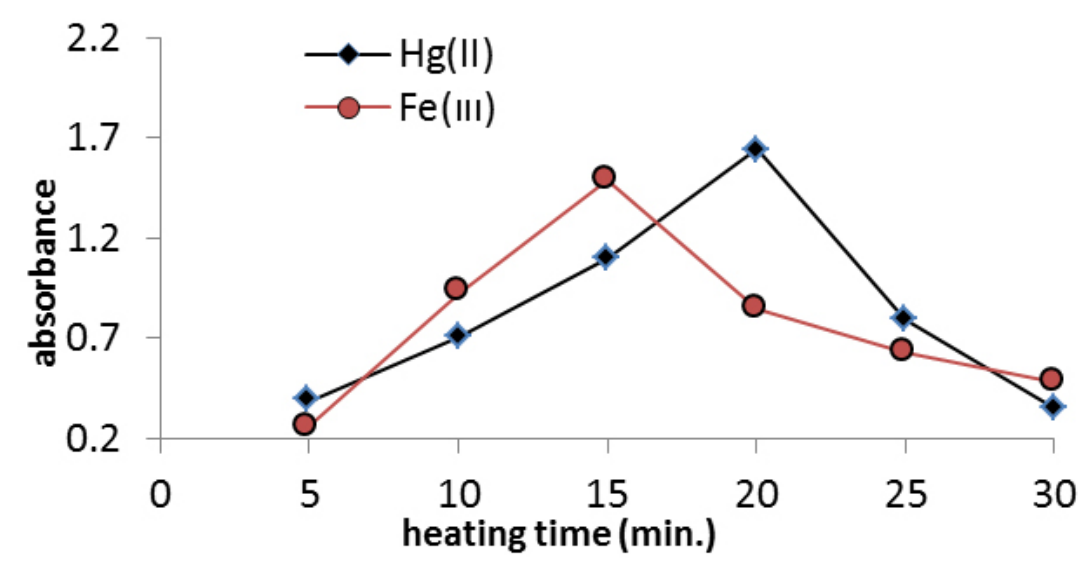

Fig. 13: heating time effect on CPL formation and onium species extracted

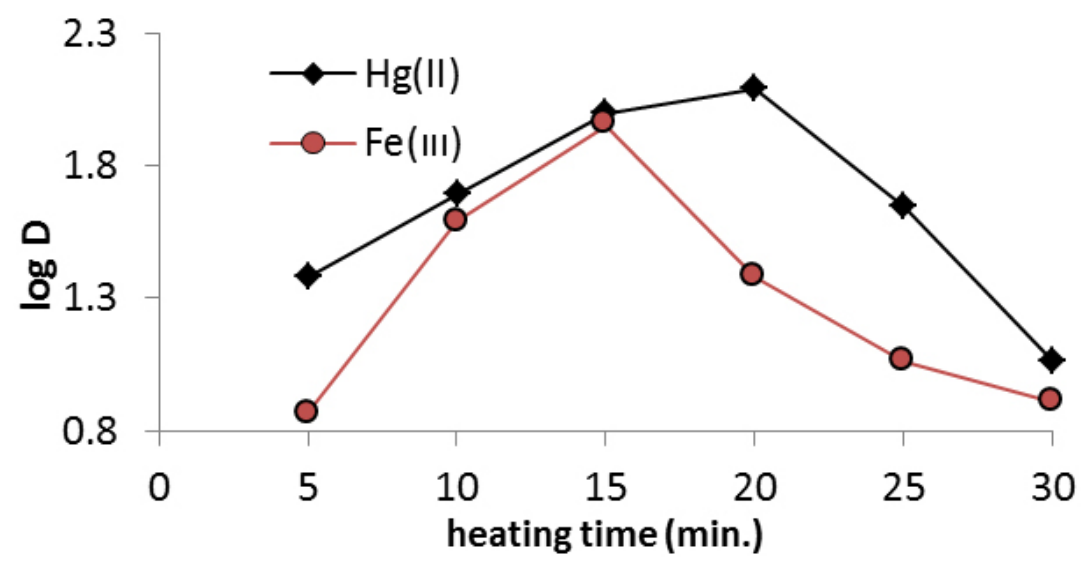

Fig. 14: heating time effect on extraction efficiency and D value.

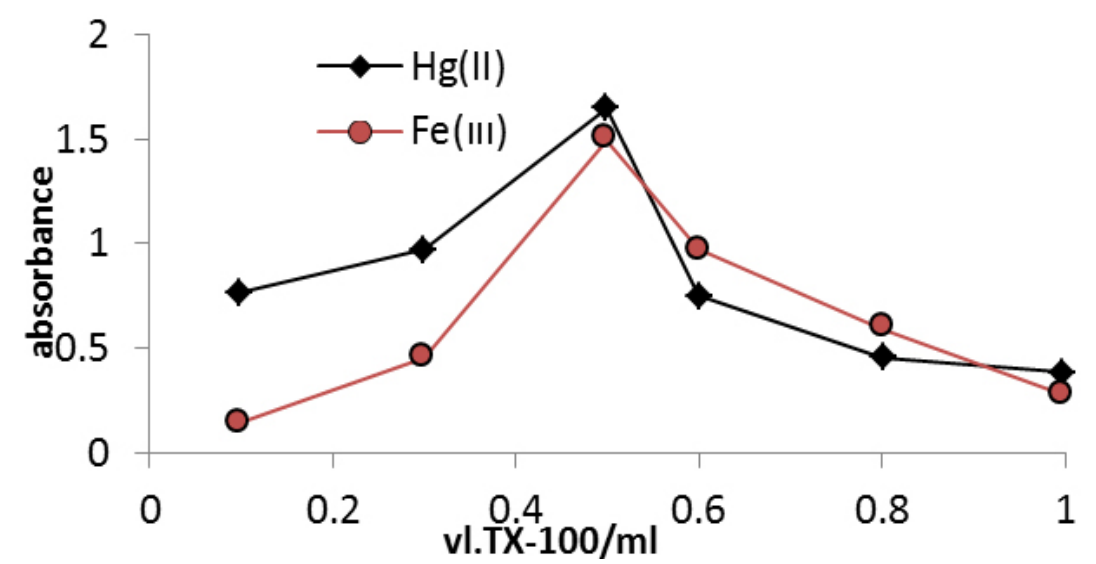

Fig. 15: effect of triton $\mathrm{X}-100$ volume on onium species concentration extracted 
to equilibrium so that at heating time more than optimum value increase the diffusion of micelles with decrease in dehydration so decrease in extraction efficiency.

\section{Effect of surfactant volume}

From $10 \mathrm{~mL}$ aqueous solutions contain $100 \mu \mathrm{g}$ of $\mathrm{Fe}^{3+} \mathrm{Or} \mathrm{Hg}^{2+}$ ions at optimum condition in existence rising volume of surfactant Triton X-100 according to comprehensive method. The results were as in Figures (15),(16). (15 and 16):

The results shows $0.5 \mathrm{ml}$ of TX-100 was the optimum surfactant volume for extraction both ion $\mathrm{Fe}^{3+}$ and $\mathrm{Hg}^{2+}$ this volume help to reached the state of critical micelles concentration CMC and produce best CPL enough to extracted higher quantity of onium species, volume less than optimum not allow to $\mathrm{CMC}$, so that volume more than optimum value and by effect of electrostatic interaction between micelles increase diffusion of micelles with decrease in CPL

\section{Effect of electrolyte salts}

Extracted metal ions according to comprehensive method at optimum condition and in presence $0.01 \mathrm{~mL}$ of different electrolytes, the results were as in table(2).

The results appear enhancement in extraction efficiency in presence electrolyte in aqueous solutions because the electrolyte doing to destroying the hydration shell of metal ion $\mathrm{Fe}^{3+}$ and $\mathrm{Hg}^{2+}$ so that cause increase in dehydration of micelles that is mean increasing in onium species concentration formation and formation good $\mathrm{CPL}_{1}$ also appear this effect differ from electrolyte to other according to behavior of electrolyte in aqueous solutions and $\mathrm{LiCl}$ giving the higher effect.

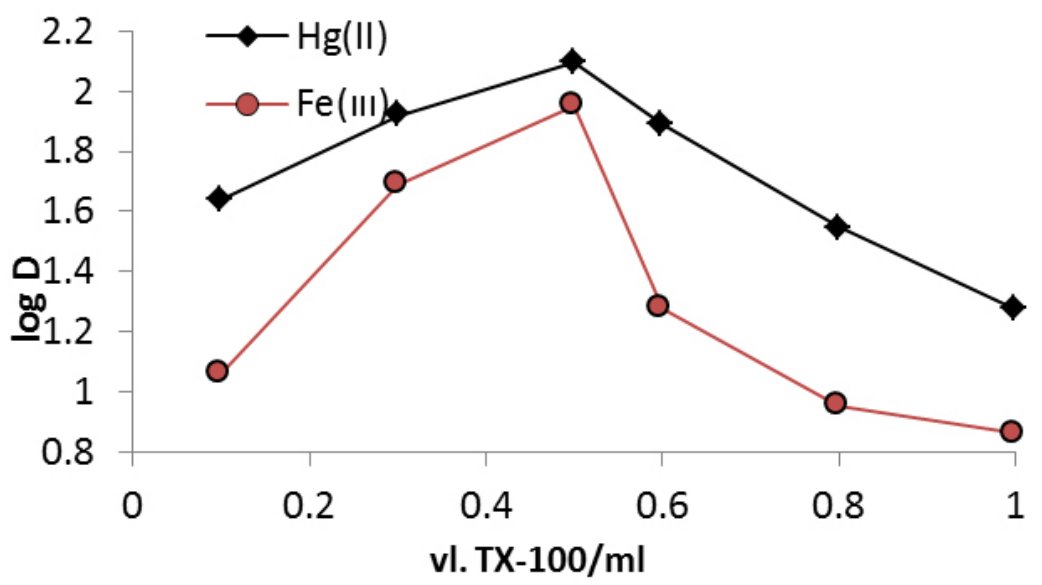

Fig. 16: effect of triton $X-100$ volume on extraction efficiency and $D$ value

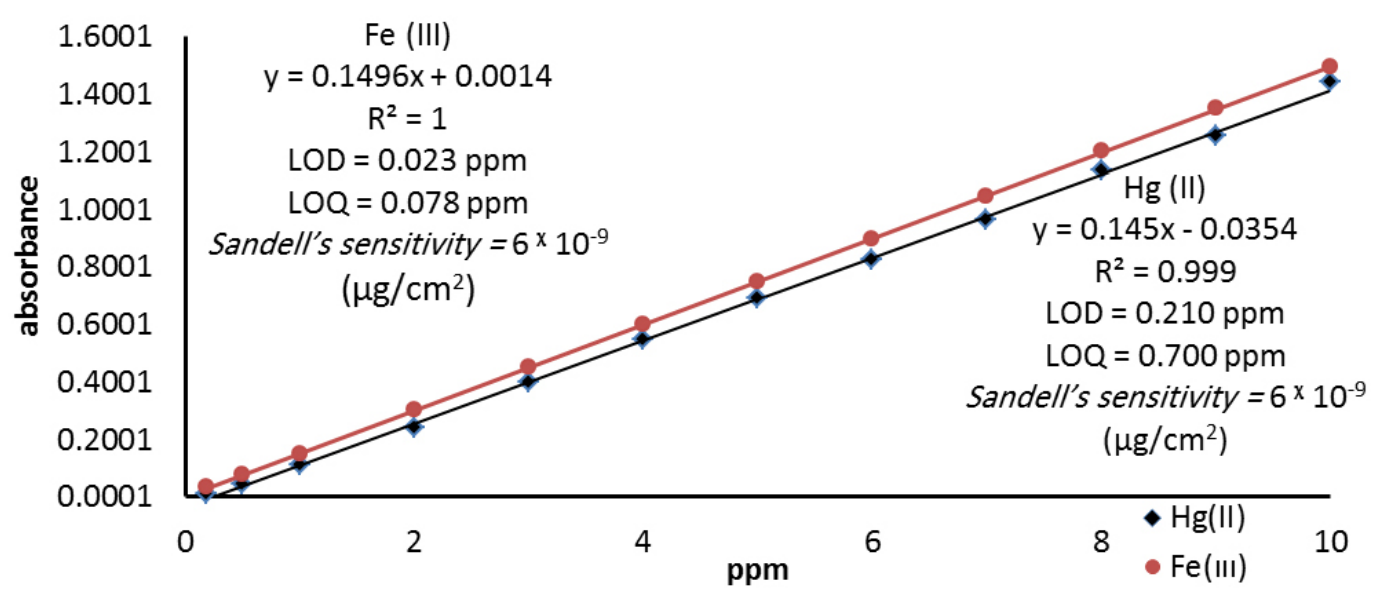

Fig. 17: calculation curve for spectrophotometric determination of $\mathrm{Fe}^{3+}$ and $\mathrm{Hg}^{2+}$ 
Table $4: \mathrm{Fe}^{3+}$ and $\mathrm{Hg}^{2+}$ content (ppm) in different samples.

\begin{tabular}{lcccccc}
\hline samples & $\mathbf{F e}^{3+}$ & \multicolumn{5}{c}{$\mathbf{H g}^{2+}$} \\
& $\begin{array}{c}\text { Thiocyanate }^{2+} \\
\text { method }^{18}\end{array}$ & $\begin{array}{c}\text { Applied } \\
\text { method }^{*}\end{array}$ & $\begin{array}{c}\text { RSD } \\
\%\end{array}$ & $\begin{array}{c}\text { Dithiazone } \\
\text { method }^{18}\end{array}$ & $\begin{array}{c}\text { Applied } \\
\text { method }^{*}\end{array}$ & $\begin{array}{c}\text { RSD } \\
\%\end{array}$ \\
\cline { 2 - 7 } agriculture 1 & 13.5 & 13.2 & 0.12 & 0.18 & 0.17 & 0.02 \\
agriculture 2 & 20.6 & 21 & 0.02 & 0.2 & 0.16 & 0.03 \\
Cow meat (Beef) & 1.5 & 1.6 & 0.14 & 0.16 & 0.2 & 0.01 \\
chicken (breast) & 7.2 & 7.4 & 0.12 & 0.16 & 0.21 & 0.05 \\
Drainage fish & 17.1 & 16.8 & 0.02 & 0.6 & 0.58 & 0.09 \\
River water & 1 & 0.9 & 0.01 & 0.48 & 0.51 & 0.01 \\
garden cress & 6.3 & 6.6 & 0.13 & 0.4 & 0.37 & 0.14 \\
celery & 5 & 5.2 & 0.15 & 0.1 & 0.09 & 0.12 \\
lettuce & 6.8 & 6.5 & 0.11 & 0.15 & 0.1 & 0.14 \\
cucumber & 5 & 5.4 & 0.01 & 0.08 & 0.1 & 0.17 \\
Tomato & 8.6 & 8.4 & 0.3 & 0.04 & 0.05 & 0.05 \\
\hline
\end{tabular}

*Values given represent the average of five analysis of each sample.

\section{Interferences effect}

From $10 \mathrm{~mL}$ aqueous solutions extracted $100 \mu \mathrm{g}$ of $\mathrm{Fe}^{3+} \mathrm{or} \mathrm{Hg}^{2+}$ ions in presence $1 \mathrm{M} \mathrm{HCl}, 1 \times 10^{-4}$ M (BAEE), $0.5 \mathrm{~mL} 1 \%$ TritonX-100 and $0.01 \mathrm{ml}$ of some interferences at optimum condition according to comprehensive method. The results were as in Table(3).

The results appear all metal cation give partially interferences and effect to decrease extraction efficiency because all these metal ion participation in formation onium species and this participation effect to decline concentration of $\mathrm{HCl}$, (BAEE), than optimum values needed to extraction $\mathrm{Fe}^{3+}$ and $\mathrm{Hg}^{2+}$ and this decline in concentration not allow to reached equilibrium of formation and extraction onium species, but by reason of different ability and behavior of these metal cation in aqueous solutions so different participation.

\section{Applications}

For spectrophotometric determination of $\mathrm{Fe}^{3+}$ and $\mathrm{Hg}^{2+}$ in different environmental and vital samples followed, the comprehensive method for extraction metal ion under study from $10 \mathrm{~mL}$ aqueous solutions contain different quantity of metal cation at all optimum conditions and after separated CPL from aqueous solutions, and dissolved CPL in $5 \mathrm{~mL}$ ethanol and measure absorbance for ethanolic solutions against blank prepared in the same method without metal ions, then plot absorbance against ppm of metal ion as in Figure 17.

Any sample after preparing treated according to comprehensive method at optimum condition after measure the absorbance and return to calibration curve for each metal ion determine metal ion in the sample. The results were as in table(4) .

\section{REFERENCE}

1. Jaric I., Jeftic Z.V., Cvijanovic G., Gacic Z., Jovanovic L., Skoric S., Lenhardt M., Microchemical Journal, 2011,98,77.

2. Lieu T., Heiskala M. ,Peterson P.A., Yang Y., Molecular Aspects of Medicine, 2001,22,1.

3. By Lab Manager Staff, Determination of
Mercury in Waters by U.S. EPA Method 245.1 Cold Vapor Atomic Absorption Spectroscopy, $2010,20$.

4. Tokalioglu S., Kartal S., Elci L., Analytica Chimica Acta, 2000, 413, 33.

5. H. Watanabe, H. Tanaka,. Talanta, 1978,25 , 
585 .

6. Jawad S.K., Azooz E.A., IMPACT: Journal of Research in Applied, Natural and Social Sciences, 2015, 1, 2.

7. Jawad S.K., Salih M.N., Journal of Natural Sciences Research, 2015 , 5, 3.

8. Jawad S.K., Hayder F.H. Journal of Eur. Chem. Bull. , $2015,4,8$.

9. Khammas Z. A-A. , Jawad S.K. , Ali I.R., Global journal of science frontier research chemistry , 2013, $13,6$.

10. Jawad S.K. , Azooz E. A. , International Journal for Sciences and Technology , 2014, $9,1$.

11. Jawad S.K., J. R. Muslim, Iraqi National J. of Chemistry , 2012,47,401-412.

12. Pytlakowska K., Kozik V., Dabioch M., Talanta, 2013 , 110, 202.
13. Jawad S.K., Azooz E.A. ,FIRE Journal of Science and Technology, 2015, 3, 261-273.

14. Jawad S.K., Khaleel L. A. , Journal of Kufa for Chemical Science, 2016 , 2, 1.

15. Shah A.Q., Kazi T.G., Baig J .A., Afridi H.I., Kanhro G.A., Arain M.B. , Kolachi N.F. and Wadhwa S.K., food and chemical toxicology, 2010 , 48 ,65-69.

16. Khammas Z. A.A., Ghali A.A., Kadhim K. H. . Iraqi National Journal of Chemistry, 2013 , 49, 25.

17. Jawad S.K., Yassin M.A., BEST: Journal of Humanities, Arts, Medicine and Sciences, 2016 , 2, 2.

18. Marczenko Z., Balcerzak M. Separation preconcentration and spectrophotometry in inorganic analysis. Amesterdam: ELSEVIER, 2000, 1 st. 